\title{
Biosorption and equilibrium isotherms study of cadmium removal by Nostoc muscorum Meg 1: morphological, physiological and biochemical alterations
}

\author{
Rabbul Ibne A. Ahad ${ }^{1} \cdot$ Smita Goswami $^{1} \cdot$ Mayashree B. Syiem ${ }^{1}$
}

Received: 3 November 2016/Accepted: 10 April 2017/Published online: 30 May 2017

(c) Springer-Verlag Berlin Heidelberg 2017

\begin{abstract}
Rice fields of Meghalaya especially in the coal mining belt receive water contaminated by effluents from mines that are known to carry harmful heavy metal ions such as $\mathrm{Cu}, \mathrm{Fe}, \mathrm{Zn}, \mathrm{Ni}, \mathrm{Cd}, \mathrm{As}, \mathrm{Pb}, \mathrm{Cr}$, etc. Cd exposure was analyzed in the cyanobacterium Nostoc muscorum Meg 1 isolated from a contaminated rice field in Sohra, Meghalaya, India. Toxicity study established $0.5 \mathrm{ppm}$ on day 3 to be the $\mathrm{LD}_{50}$. At $\mathrm{LD}_{50}$ chlorophyll $a$ and total protein concentration was reduced by 50.9 and $52.5 \%$, while nitrogenase and glutamine synthetase activities were inhibited by 40.8 and $38.4 \%$. EDX and FTIR analyses confirmed Cd binding and participation of hydroxyl, carbonyl, carboxyl and phosphate groups in biosorption of $\mathrm{Cd}$ onto the cell surfaces. SEM study established morphological changes. At $\mathrm{pH} 8.0$ and temperature $25 \pm 2{ }^{\circ} \mathrm{C}$, the cyanobacterium removed $92 \% \mathrm{Cd}$ within $24 \mathrm{~h}$. Of this, $91 \% \mathrm{Cd}$ was adsorbed on the cell surface while $4 \%$ was internally accumulated. The energy required for internal accumulation of $\mathrm{Cd}$ was partly provided in the form of ATP synthesized during active photosynthesis. The Langmuir isotherm was found best fitted with a $R^{2}$ value 0.98 when compared to Freundlich and Temkin adsorption isotherms. The maximum sorption capacity, $Q_{\max }$, of the organism was $71.4 \mathrm{mg}$ of Cd per $\mathrm{g}$ of biomass. $R_{\mathrm{L}}$ value of 0.29 indicated favorable interaction between cyanobacterial biomass and $\mathrm{Cd}$. The adsorption intensity, $n$ value $7.69 \mathrm{~g} / \mathrm{L}$ obtained from Freundlich isotherm showed that the organism possessed high Cd sorption capacity.
\end{abstract}

Mayashree B. Syiem

mayashreesyiem@yahoo.co.in

1 Department of Biochemistry, North-Eastern Hill University, Shillong, Meghalaya 793022, India
Keywords Nostoc muscorum Meg 1 - Growth · Cadmium removal · Biosorption · FTIR · SEM

\section{Introduction}

In recent times, metal pollutants are increasing in the environment with increase in anthropogenic activities including mining and release of industrial and agricultural effluents (Gupta and Rastogi 2008). Metals are harmful and non-degradable with the possibility of accumulation and bio-magnification in organisms (Dietz et al. 2000; Gallego et al. 2012). Although metals such as $\mathrm{Cu}, \mathrm{Fe}, \mathrm{Zn}, \mathrm{Mg}, \mathrm{Mn}$, $\mathrm{Ni}$ and Mo are essential for living organisms, they can be toxic at elevated levels (DRI reports 2001). Many others such as $\mathrm{Cd}, \mathrm{Hg}, \mathrm{Cr}$, As and $\mathrm{Pb}$ have no known biological importance and are highly toxic to living organisms even at very low concentrations (Qaiser et al. 2007). Among these, $\mathrm{Cd}$ is a common pollutant that is a potent mutagenic and carcinogenic agent. Exposure to this metal can damage lungs, bones, liver, nervous tissue, gastrointestinal tract and kidney (Jin et al. 2003; Waalkanes 2003).

There are methods such as chemical treatment, solvent extraction, evaporation upturn, application of ion-exchange and membrane technologies that have been investigated for removing heavy metal burden from polluted sites (Babu and Gupta 2008; Haritash and Kaushik 2009). In recent times, metal removal by biological materials such as plants, algae and bacteria is gaining popularity due to issues related to cost and degradation efficiency. Microorganisms can reduce heavy metals load from the surrounding by mechanisms such as biosorption, bioaccumulation, biotransformation or bio-mineralization (Umrania 2006; Xiao et al. 2010). Among microbes, cyanobacteria offer attractive possibilities as they are both photosynthetic and 
diazotrophic requiring a simple nutrient input with fast growth rate that provides large surface area for metal binding. Many produce mucilage that also aids in metal removal process (Gupta and Rastogi 2008; Latifi et al. 2009; Dixit and Singh 2013). Metal remediation by living organisms could be tricky as different organisms show differential tolerance towards same metal and different metals may not result in similar effects on the organisms (Deniz et al. 2011; Gaber et al. 2012; Dixit and Singh 2013; Goswami et al. 2015a, b). Thus, for metal remediation technology to be effective, individual organisms need to be assessed for their metal removal potential. Many microbes in the presence of toxic heavy metals develop different strategies such as metal exclusion, sequestration of metals in polyphosphate bodies, metal chelation by producing metallothioneins and phytochelatin to overcome their harmful effects (Keasling and Hupf 1996; Cobette 2000). However, Mallick and Rai (1994) had shown that high concentrations of $\mathrm{Cd}$ disrupt cyanobacterial metabolism either by inactivating the photosynthetic machinery or enzymatic pathways. $\mathrm{Cd}$ at high concentration causes substantial changes in physiological and biochemical parameters and leads to enhanced reactive oxygen species production (Atri and Rai 2003).

The cyanobacterium Nostoc muscorum Meg 1 taken for this study was isolated from a rice field in Sohra, Meghalaya, India that receives contaminated water from coal mine effluents. Its existence in contaminated fields established that the organism was tolerant towards various contaminants including heavy metals. An atomic absorption spectroscopic study of the soil sample from the site recorded the presence of various metal ions $(0.32 \mathrm{ppm} \mathrm{Fe}$; 0.22 ppm Cd; 0.16 ppm Cr; 0.14 ppm Zn; 0.06 ppm Pb and $0.05 \mathrm{ppm} \mathrm{Cu}$ ). Of these, the $\mathrm{Cd}$ and $\mathrm{Pb}$ were two nonessential metal ions with $\mathrm{Cd}$ concentration being much higher than that of $\mathrm{Pb}$. One must understand that the concentration of various contaminants may change from time to time depending on the amount of coal residues that enters the rice fields with water, especially during rainy season. Heavy metals including $\mathrm{Cd}$ gets accumulated in crops (Murakami et al. 2008; Zhang et al. 2014) and further gets concentrated along the food chain creating threat of chronic exposure in animals and humans producing adverse affects as mentioned above. Rice fields provide conducive atmosphere for cyanobacterial growth in terms of availability of light, water and nutrients whereas in turn, these organisms provide fixed nitrogen on their turn over to the rice crop (Prasanna et al. 2014). In addition to this biofertilizer potential, many researchers have also established cyanobacteria's metal binding abilities (Hazarika et al. 2015; Khan et al. 2016). Thus, when present in rice fields, in addition to providing fixed nitrogen, by binding metal ions from surrounding these organisms reduce the harmful metal load that the crop plants get exposed to.

In our laboratory, we are looking into the effects of various metal ions on different cyanobacteria as well as metal removal efficiency of this group of microbes. The high concentration of $\mathrm{Cd}$ in the rice field from where the organism was isolated presented an intriguing proposal to study $\mathrm{Cd}$ removal efficiency and $\mathrm{Cd}$ induced changes in the organism Nostoc muscorum Meg 1. In the article, a comprehensive study of $\mathrm{Cd}$-induced morphological, physiological and biochemical alterations to the organism is presented. Also, kinetics of $\mathrm{Cd}$ biosorption and equilibrium isotherms were investigated in detail.

\section{Materials and methods}

\section{Identification and maintenance of the organism}

Soil sample was collected from a rice field of Sohra adjacent to a coal mining site, Meghalaya, India and was diluted in double-distilled water prior to inoculating in freshly prepared $\mathrm{BG} 11_{0}$ medium $(\mathrm{pH} 8)$ to allow growth of cyanobacteria (Ripkka et al. 1979). After a period of 10 days, the growing cyanobacterial filaments were purified by repeated plating on $1.5 \%$ agar supplemented media (Rippka 1988). MiniPrep bacterial genomic DNA method (Ausubel et al. 1999) was used to extract genomic DNA from the cyanobacterium. 16S rRNA gene from the isolated DNA was amplified by PCR and sequenced. DNA sequencing reaction was carried out in Xceleris Laboratory, Ahmedabad, India with CY106F (5'-CGG ACG GGT GAG TAA CGC GTG A-3') and CY781R \{equimolar mixture of CY781R(A) 5'-GAC TAC TGG GGT ATC TAA TCC CAT T-3' and CY781R(B) 5'-GAC TAC AGG GGT ATC TAA TCC CTT $\left.\mathrm{T}_{-} 3^{\prime}\right\}$ primers using BDT v3.1 cycle sequencing kit on $3730 \times 1$ Genetic Analyzer (Applied Biosystems, USA) (Nubel et al. 1997). Related sequences were retrieved from NCBI Genbank database using BLAST and first 15 sequences were used based on maximum identity score and aligned using multiple alignment software program Clustal W. Distance matrix was generated using RDP database and the phylogenetic tree was constructed using MEGA 5 (Tamura et al. 2011). The isolate was maintained inside a culture room at a $\mathrm{pH} 8$, temperature $\left(25 \pm 2{ }^{\circ} \mathrm{C}\right)$ and light at a photon fluence rate $\left(50 \mu \mathrm{mol} / \mathrm{m}^{2} \mathrm{~s}^{1}\right) \quad$ (Hazarika et al. 2015). Ten-day-old exponential phase cyanobacterial cells at initial culture concentration of $3 \mu \mathrm{g} / \mathrm{mL}$ chlorophyll $a$ were used for all experiments carried out. 


\section{Chemicals and reagents}

All the chemicals procured in this study were of analytical grade supplied by Sigma-Aldrich, India, Sisco Research Laboratory and HiMedia Laboratories Pvt. Ltd.

\section{Metal treatment}

$3 \mathrm{CdSO}_{4} .8 \mathrm{H}_{2} \mathrm{O}$ was used as the source of $\mathrm{Cd}$ for all the experiments. Experimental $\mathrm{Cd}$ solution was prepared by diluting a stock solution of $100 \mathrm{ppm}$ with medium. To establish the upper limit of Cd concentration for the study, an initial $\mathrm{Cd}$ removal study was carried in cultures supplemented with $0.1,0.2,0.3,0.5,1.0,1.5,2,2.5,3,3.5,4,5$ and $10 \mathrm{ppm}$ of $\mathrm{Cd}$. The maximum removal found in $3 \mathrm{ppm}$ Cd-supplemented medium and beyond which it remained almost constant. Hence, maximum $\mathrm{Cd}$ concentration up to $5 \mathrm{ppm}$ is presented in this study.

\section{FTIR spectroscopy analysis}

Five $\mathrm{mL}$ of control and Cd-treated cultures was transferred after $24 \mathrm{~h}$ treatment in $0.5 \mathrm{ppm}$ of Cd onto Petri-plates and dried in an oven at $40{ }^{\circ} \mathrm{C}$. Dried samples were mixed with desiccated spectroscopic-grade potassium bromide, 1:10 (w/w) to make pellets. Fourier transform infrared spectroscopic analysis was performed using Perkin Elmer, 400 FTIR/FT-FIR Spectrometer; model: SP400 operating in the range of $4000-450 \mathrm{~cm}^{-1}$ to determine various cell surface functional groups in metal binding.

\section{EDX analysis}

EDX analysis was done using INCA Penta FETX3 in combination with SEM, JEOL-JSM-6360; JEOL, Tokyo, Japan. The raw samples were pre-treated with $4 \%$ glutaraldehyde for $24 \mathrm{~h}$ at $4{ }^{\circ} \mathrm{C}$ followed by washing in $0.1 \mathrm{M}$ sodium cacodylate buffer thrice at an interval of $15 \mathrm{~min}$. Dehydration was carried out in acetone $(30,50,70,80,90$, 95 and 100\%). The dehydrated samples were mounted on brass stubs and gold coated before viewing.

\section{Cadmium removal and its distribution in the cell}

Metal removal was analyzed using GF-AAS (Analytik Jene AG Vario 6) (Nongrum and Syiem 2012). $20 \mathrm{~mL}$ cultures treated for $24 \mathrm{~h}$ with $0.5,1.0,1.5,2.0,2.5,3,3.5,4.0$ and $5 \mathrm{ppm} \mathrm{Cd}$ were centrifuged at $3000 \mathrm{rpm}$ for $10 \mathrm{~min}$ and the amount of metal in the supernatant was analyzed. Percent cadmium removal was calculated using the Eq. 1.

$\%$ Cd removal $=\frac{\left(C_{\mathrm{I}}-C_{\mathrm{F}}\right)}{C_{\mathrm{I}}} \times 100$ where $C_{\mathrm{I}}$ is the cadmium concentration initially present in the medium; $C_{\mathrm{F}}$ is the remaining $\mathrm{Cd}$ concentration in the supernatant.

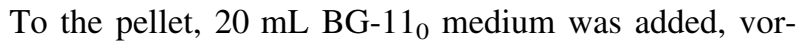
texed for $2 \mathrm{~min}$ and centrifuged at $3000 \mathrm{rpm}$ for $5 \mathrm{~min}$. The supernatant was analyzed for metal precipitated on the cell surface. Next, $20 \mathrm{~mL}$ of $0.1 \mathrm{M} \mathrm{HCl}$ solution was added to the pellet and left for 2 min before vortexing vigorously to desorb surface bound metal ions. Desorbed amount of $\mathrm{Cd}$ ions was determined in the supernatant collected after centrifugation. After this step, the residual pellet was resuspended in $20 \mathrm{~mL}$ medium, ruptured by ultrasonication (Sonics Vibra cell sonicator, VC-505, USA fitted with a microprobe) for $3 \mathrm{~min}$ and the resulting solution was used for determination of intracellularly accumulated $\mathrm{Cd}$.

\section{Provision of energy for cadmium accumulation}

The energy requirement, if any, for the process of biosorption and intracellular accumulation was studied by setting up four experiments. Cyanobacterial cells $(3 \mu \mathrm{g} /$ $\mathrm{mL}$ ) were added in $20 \mathrm{~mL}$ BG- $11_{0}$ medium containing $0.5 \mathrm{ppm} \mathrm{Cd}$ and incubated at $25 \pm 2{ }^{\circ} \mathrm{C}$ for $24 \mathrm{~h}$ in the following conditions: (a) continuous light (b) dark (c) continuous light in presence of a photosynthetic inhibitor DCMU, $(10 \mu \mathrm{M})$ and (d) in dark in the presence of ATP, $(10 \mu \mathrm{M})$. After $24 \mathrm{~h}$ incubation, solutions were centrifuged at $3000 \mathrm{rpm}$ for $3 \mathrm{~min}$ and supernatants were taken for Cd analysis by AAS.

\section{Biosorption isotherms}

Cd biosorption was analyzed using — Langmuir, Freundlich and Temkin isotherms (Aharoni and Ungarish 1977; Volesky and Holan 1995). Cells incubated in 0.5, 1.0, 1.5, 2.0, 2.5, 3, 3.5, 4 and $5 \mathrm{ppm} \mathrm{Cd}$ for $24 \mathrm{~h}$ were centrifuged and the supernatant was analyzed using AAS.

\section{Langmuir isotherm}

The amount of Cd taken up by the Nostoc muscorum Meg 1 cells was expressed as $q(\mathrm{mg} / \mathrm{g})$ and was calculated from $C_{\mathrm{I}}, C_{\mathrm{F}}, v$ and $w$ where $C_{\mathrm{I}}, C_{\mathrm{F}}$, are the initial and final metal concentrations, respectively, $v$ is the volume of medium in $\mathrm{mL}$ and $w$ is the biomass weight in $\mathrm{g}$.

$q=\frac{\left(C_{\mathrm{I}}-C_{\mathrm{F}}\right) \times v}{w}$

Langmuir equation is based on the following assumptions: (a) adsorbent has finite numbers of energetically uniform sites, (b) interaction among the adsorbed species are not found and (c) adsorbed species 
always form a monolayer on the adsorbent surface beyond which no further adsorption takes place. The Langmuir's isotherm can be expressed as:

$q_{\mathrm{F}}=\frac{Q_{\max } \times K_{\mathrm{L}} \times C_{\mathrm{F}}}{1+K_{\mathrm{L}} \times C_{\mathrm{F}}}$

where $q_{\mathrm{F}}$ is the amount of metal adsorbed in mg per $\mathrm{g}$ of biosorbent at equilibrium, $Q_{\max }$ is the maximum adsorption capacity per unit weight per $g$ for the metal ions needed for complete formation of monolayer on the biosorbent surface and $K_{\mathrm{L}}$ refers the adsorption equilibrium constant related to the binding affinity.

Using the Langmuir equation, the separation factor $\left(R_{\mathrm{L}}\right)$ was calculated by the following Eq. 4 .

$R_{\mathrm{L}}=\frac{1}{1+K_{\mathrm{L}} \times C_{\mathrm{I}}}$

$R_{\mathrm{L}}$ is a dimensionless equilibrium parameter which can determine the nature of interaction of the biomass with the metal ions. If $R_{\mathrm{L}}$ value is $>1$, it indicates the unfavorable interaction whereas $R_{\mathrm{L}}=1$ indicates linear interaction between metal and the biosorbent and $R_{\mathrm{L}}<1$ shows favorable interaction. An $R_{\mathrm{L}}=0$ indicates irreversible interaction (Oguz 2005).

\section{Freundlich isotherm}

Freundlich adsorption isotherm that is used to describe adsorption on a heterogeneous surface assume that enthalpy of adsorption is independent of the metal adsorbed. Freundlich isotherm can be expressed as:

$q_{\mathrm{F}}=K_{\mathrm{F}} \times C_{\mathrm{F}}^{1 / n}$

where $K_{F}$ and $n$ are the Freundlich constant related to sorption capacity and intensity.

\section{Temkin isotherm}

Temkin isotherm model relates to interaction between adsorbent and adsorbate and takes into account that the free energy of adsorption is a function of surface coverage. It presumes that adsorption of all the molecules in the layer decreases linearly and not logarithmically.

Temkin isotherm can be expressed as:

$q_{\mathrm{F}}=\frac{\mathrm{RT}}{b_{\mathrm{T}}} \ln \left(A_{\mathrm{T}} C_{\mathrm{F}}\right)$

$B=\frac{\mathrm{RT}}{b_{\mathrm{T}}}$

$q_{\mathrm{F}}=B \ln A_{\mathrm{T}}+B \ln C_{\mathrm{F}}$

where $R$ is the universal gas constant $(\mathrm{J} / \mathrm{mol} / \mathrm{K}), T$ is the temperature in $\mathrm{K}, b_{\mathrm{T}}$ is the Temkin isotherm constant
( $\mathrm{J} / \mathrm{mol}), A_{\mathrm{T}}$ is the Temkin isotherm equilibrium binding constant $(\mathrm{L} / \mathrm{mg})$ corresponding to the maximum binding energy and $C_{\mathrm{F}}$ is the equilibrium concentration $(\mathrm{mol} / \mathrm{L})$ of the adsorbate and $B$ is the constant related to heat of sorption $(\mathrm{J} / \mathrm{mol})$.

\section{Morphological, physiological and biochemical changes}

Changes in all the morphological and biochemical parameters upon $\mathrm{Cd}$ treatment were studied in $\mathrm{LD}_{50}$ (0.5 ppm Cd).

\section{Morphological studies}

Morphological changes were observed under SEM when cells were exposed for 3 days. Samples for SEM were prepared following pre-fixation and dehydration procedure described under EDX analysis.

\section{Estimation of chlorophyll a}

Three $\mathrm{mL}$ of experimental culture was centrifuged and to the pellet $3 \mathrm{~mL}$ methanol was added. This was kept at $4{ }^{\circ} \mathrm{C}$ overnight for chlorophyll $a$ extraction. At the end of the incubation, the solution was centrifuged and absorbance was read at $663 \mathrm{~nm}$ using UV-Vis spectrophotometer (Smart Spec Plus; Bio Rad, USA) and chlorophyll $a$ concentration was calculated using the formula described by MacKinney 1941.

\section{Protein estimation}

Cyanobacterial culture $(3 \mathrm{~mL})$ was centrifuged at $2500 \mathrm{rpm}$ for $3 \mathrm{~min}$ and the pellet resuspended in milliQ water (volume to $3 \mathrm{~mL}$ ). The cells were disrupted by ultrasonication and $0.5 \mathrm{~mL}$ of the resulted solution was taken and the volume was made up to $1 \mathrm{~mL}$ with milliQ water. $5 \mathrm{~mL}$ of solution $\mathrm{C}$ which was made by mixing $98 \mathrm{~mL}$ Solution $\mathrm{A}\left(2 \% \mathrm{Na}_{2} \mathrm{CO}_{3}\right.$ in $\left.0.1 \mathrm{~N} \mathrm{NaOH}\right)$ and $2 \mathrm{~mL}$ solution $\mathrm{B}\left(0.5 \% \mathrm{CuSO}_{4}\right.$ and $1 \% \mathrm{C}_{4} \mathrm{H}_{4} \mathrm{KNaO}_{6} \cdot 4 \mathrm{H}_{2} \mathrm{O}$ in the ratio of 0.5:5) was added to each test tube and incubated for $20 \mathrm{~min}$ in room temperature. This was followed by immediate addition of $0.5 \mathrm{~mL} 1 \mathrm{~N}$ Folin-Ciocalteu's phenol reagent to the test tubes and kept for $10 \mathrm{~min}$. The developed color solution was read at $750 \mathrm{~nm}$ against reference blank and the concentration was calculated using a standard curve (Lowry et al. 1951).

\section{Heterocyst frequency and nitrogenase activity}

Heterocysts frequency of the cyanobacterial cells was calculated according to Wolk (1965). At least 500 cells 
were counted for each calculation under Olympus light microscope BX-53.

Nitrogenase activity was measured by following the acetylene reduction assay method described by Stewart et al. (1967). In a $15 \mathrm{~mL}$ vial, $5 \mathrm{~mL}$ of cyanobacterial culture was added and air phase was replaced by $10 \%(\mathrm{v} /$ v) acetylene. This was followed by incubation of all the vials at $25 \pm 2{ }^{\circ} \mathrm{C}$ for $1 \mathrm{~h}$ in the presence of light with continuous shaking. Gas chromatography (Varian 3900, The Netherlands) fixed with a Porapak $\mathrm{T}$ column (stainless steel column $6^{\prime} \times 1 / 8^{\prime \prime}$, Porapak $\mathrm{T}$ of mesh size 80/100) and a flame ionization detector was used to estimate the amount of reduced acetylene. Activity of enzyme nitrogenase was expressed as nmol of $\mathrm{C}_{2} \mathrm{H}_{2}$ reduced $/ \mu \mathrm{g}$ chl $a / h$.

\section{Glutamine synthetase (transferase) activity}

Cyanobacterial culture $(3 \mathrm{~mL})$ was centrifuged and the pellet was washed twice with $50 \mathrm{mM}$ Tris- $\mathrm{HCl}$ buffer, $\mathrm{pH}$ 7.5 and resuspended in the same buffer. The cells were disrupted using ultra-sonicator to release the enzyme into the buffer. To $0.5 \mathrm{~mL}$ of the sonicated cultures, $0.5 \mathrm{~mL}$ of assay mixture that contained $40 \mathrm{mM}$ Tris- $\mathrm{HCl}$ buffer $(\mathrm{pH}$ 7.5), $3 \mu \mathrm{M} \mathrm{MnCl}_{2}, 20 \mu \mathrm{M}$ of potassium arsenate, $0.4 \mu \mathrm{mol}$ of ADP (sodium salt), $60 \mu \mathrm{mol}$ of hydroxylamine and $30 \mu \mathrm{mol}$ of glutamine were added and incubated at $30 \pm 2{ }^{\circ} \mathrm{C}$ for $10 \mathrm{~min}$ in dark. $2 \mathrm{~mL}$ of stop mixture $(10 \%$ $\mathrm{FeCl}_{3}, 24 \%$ TCA, $6 \mathrm{M} \mathrm{HCl}$ in distilled water) was added to the above solution to stop the enzymatic reaction. This was followed by centrifugation at $2000 \mathrm{rpm}$ for $5 \mathrm{~min}$ and the supernatant collected was read at $540 \mathrm{~nm}$. The $\gamma$-glutamyl hydroxamate produced in the reaction was estimated by plotting the absorbance value in a standard curve described by Sampaio et al. (1979). Activity of GS was expressed as nmol of $\gamma$-glutamyl hydroxamate produced $/ \mu \mathrm{g}$ of protein/ $\min$.

\section{Results}

\section{Identification of the organism}

Under light microscope (Olympus BX-53), the isolated organism was identified as Nostoc muscorum (Desikachary 1959). Its phylogenetic analyses carried out by comparing amplified partial sequences of 16S rRNA gene with similar sequences deposited in GenBank (NCBI) showed high although not $100 \%$ similarity to Nostoc muscorum 19 and was thus positioned near Nostoc muscorum 19 and named as Nostoc muscorum Meg 1 (GenBank Accession No. KM596855).

\section{FTIR analysis}

FTIR analysis showed significant spectral variations in the Cd-treated cells in comparison to control cultures (Fig. 1). A shift in the frequency of the FTIR spectra reflects change brought about by binding of the metal ion on the functional groups. Shift seen in the region $3830 \rightarrow 3849 \mathrm{~cm}^{-1}$ established involvement of hydroxyl group. A shift towards the lower frequency from $3431 \rightarrow 3444 \mathrm{~cm}^{-1}$ and from $2271 \rightarrow 2294 \mathrm{~cm}^{-1}$ indicated the possible participation of $\mathrm{O}-\mathrm{H}$ stretching and phosphate group in form of phosphine ligands for metal binding. Shift in frequency from $1456 \rightarrow 1468 \mathrm{~cm}^{-1}, \quad 1400 \rightarrow 1408 \mathrm{~cm}^{-1}, \quad 1191 \rightarrow$ $1238 \mathrm{~cm}^{-1}$ and $1079 \rightarrow 1094 \mathrm{~cm}^{-1}$ corresponded to involvement of O-H (phenol ring), carboxyl, acyl/phenyl $\mathrm{C}-\mathrm{O}$ group and alcohol $\mathrm{C}-\mathrm{O}$ stretch. Change in frequency from $501 \rightarrow 518 \mathrm{~cm}^{-1}$ and $475 \rightarrow 482 \mathrm{~cm}^{-1}$ reflected the participation of phosphate group in $\mathrm{Cd}$ binding.

\section{EDX analysis}

Energy-dispersion spectra of the characteristic EDX of control and $0.5 \mathrm{ppm} \mathrm{Cd}$-treated cells for $24 \mathrm{~h}$ are presented in Fig. 2. The presence of a $\mathrm{Cd}$ peak in the Cd-treated sample (Fig. 2b) and its absence in the control culture provided evidence of $\mathrm{Cd}$ binding on the cell surfaces of the treated cells.

\section{Metal removal and its cellular distribution}

Nostoc muscorum Meg 1 cells at a concentration of $3 \mu \mathrm{g} /$ $\mathrm{mL}$ chlorophyll $a$ were treated with $0.5,1,1.5,2,2.5,3$, 3.5, 4 and $5 \mathrm{ppm} \mathrm{Cd}$ for $24 \mathrm{~h}$ to record $\mathrm{Cd}$ removal by the cells (Fig. 3). Removal of $\mathrm{Cd}$ ions was found to be a concentration-dependent process; the amount removed was directly proportional to the initial $\mathrm{Cd}$ concentration provided in the medium. The amount of $\mathrm{Cd}$ removed within $24 \mathrm{~h}$ increased from 0.46 to $3.27 \mathrm{ppm}$ when initial $\mathrm{Cd}$ concentration in the medium was raised from 0.5 to $5 \mathrm{ppm}$. However, increase in percent $\mathrm{Cd}$ removal was very nominal $(92-96.3 \%$ in the medium supplemented with $0.5-3 \mathrm{ppm})$. Beyond $3 \mathrm{ppm}$, the percent $\mathrm{Cd}$ removal declined to $65.4 \%$ in 5 ppm Cd-supplemented medium. This result indicated that when $\mathrm{Cd}$ concentration beyond $3 \mathrm{ppm}$ is raised in the medium, the $\mathrm{Cd}$ on to the cell surfaces of the organism reached a saturation limit and any increase in externally supplied concentration in the medium could not be taken up proportionally by the cells.

Figure 4 represents the distribution of $\mathrm{Cd}$ in the Nostoc muscorum Meg 1 cells treated with $0.5 \mathrm{ppm} \mathrm{Cd}$ supplemented medium for $24 \mathrm{~h}$. $92 \%$ of the supplemented $\mathrm{Cd}$ amounting to $0.46 \mathrm{ppm} \mathrm{Cd}$ was removed by the Nostoc 
Fig. 1 FTIR spectra of Nostoc muscorum Meg 1 cell surface of control and Cd-treated cells

Fig. 2 Energy-dispersion spectra of the characteristic EDX in control and Cd-treated cells of Nostoc muscorum Meg 1. a Control, $\mathbf{b}$ cells treated with $0.5 \mathrm{ppm} \mathrm{Cd}$. Arrow indicates $\mathrm{Cd}$ peak in the EDX spectra
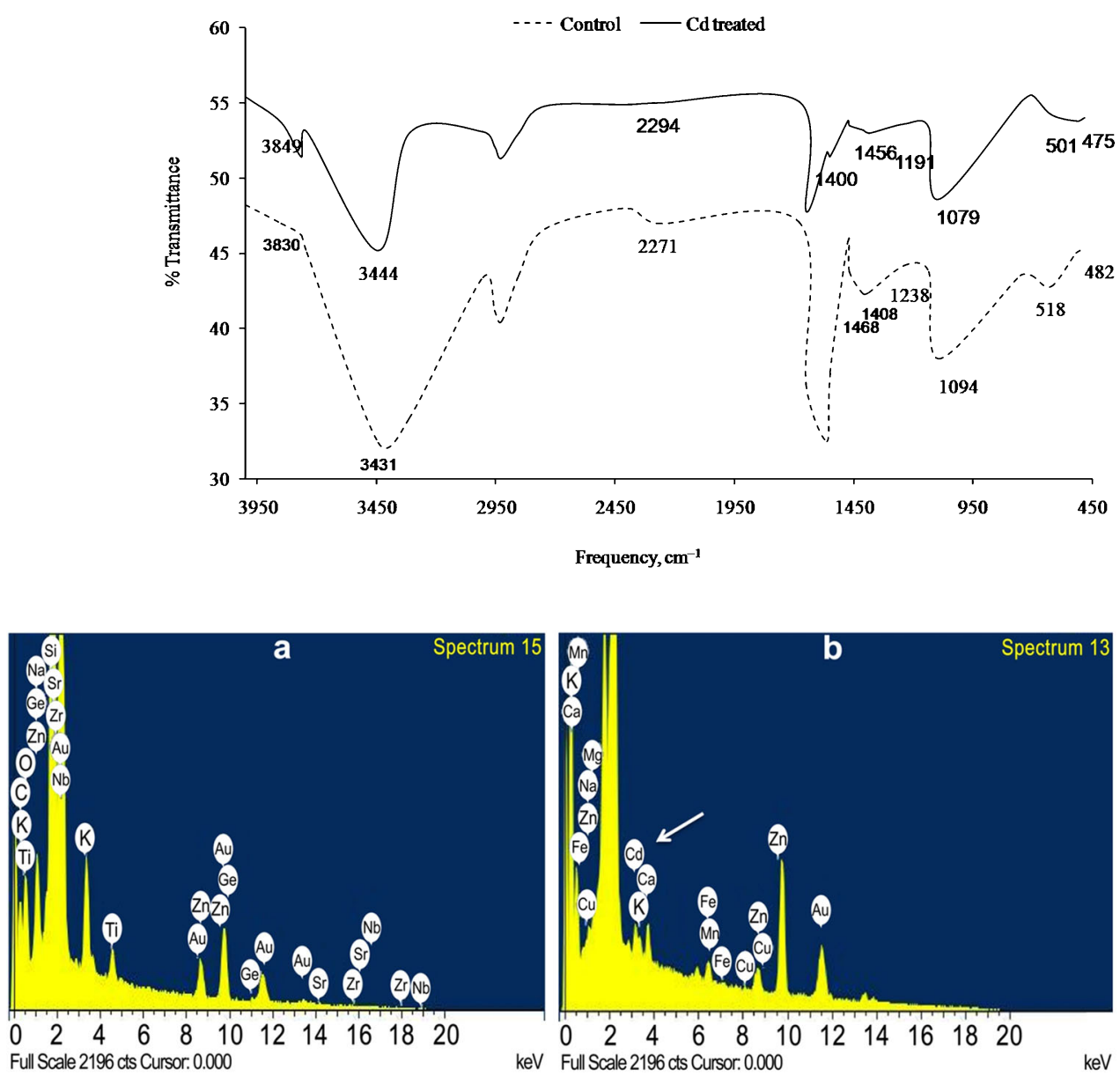

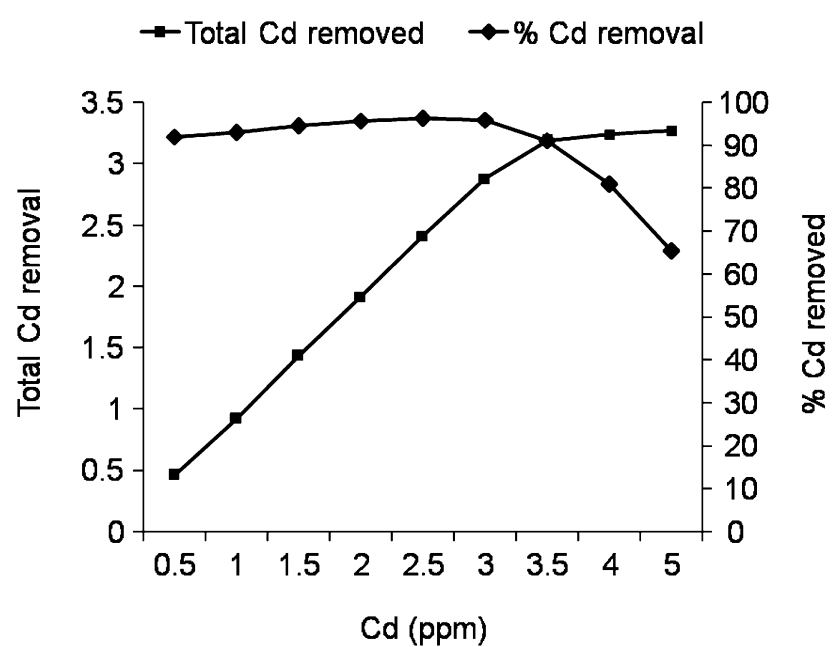

Fig. 3 Total and percent Cd removal by Nostoc muscorum Meg 1 cells within $24 \mathrm{~h}$

muscorum Meg 1 cells during this period (Fig. 4a). Of this total $\mathrm{Cd}$ removed, $91 \%$ was found adsorbed on the cell surface indicating the $\mathrm{Cd}$ removal process to be primarily biosorption. Further analysis showed $4 \%$ of the removed $\mathrm{Cd}$ precipitated on the cell surface that could be easily removed by shaking and $4 \%$ was internally accumulated that could be accessed only upon disruption of cells (Fig. 4b).

\section{Energy provision}

As shown in Fig. 5, the cyanobacterium was able to remove $92 \%$ of $\mathrm{Cd}$ when incubated for $24 \mathrm{~h}$ in continuous light from the medium containing $0.5 \mathrm{ppm} \mathrm{Cd}$. Same experiment conducted in dark resulted in $88.2 \%$ of $\mathrm{Cd}$ removal. When photosynthetic electron transport chain was blocked by DCMU in the experiment conducted in the presence of continuous light, Nostoc muscorum Meg 1 cells were able to remove $87.9 \% \mathrm{Cd}$. The almost similar amount of $\mathrm{Cd}$ removed $(88.2 \%$ in dark and $87.9 \%$ in the presence of DCMU in light) indicated that Cd removal did not require energy that could have been provided by photosynthetic electron transport chain activity in the form of ATP. However, addition of ATP in the experiment carried out in dark resulted in $92.4 \% \mathrm{Cd}$ removal-a value similar to that obtained in the experiment carried out in the presence of continuous light where photosynthesis was active in culture and ATP and reductants were produced in the light reaction of photosynthesis for carbon fixation. In both 
Fig. 4 a Percent Cd removal; and $\mathbf{b}$ distribution of removed $\mathrm{Cd}$ in the Nostoc muscorum Meg 1 cells. Medium was supplemented with $0.5 \mathrm{ppm} \mathrm{Cd}$ and the duration of the treatment was $24 \mathrm{~h}$

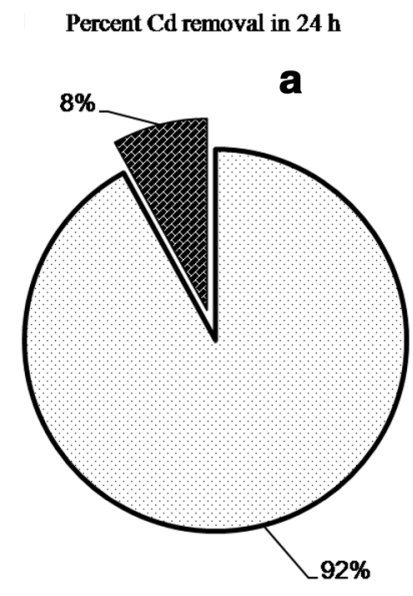

Total Cd removed

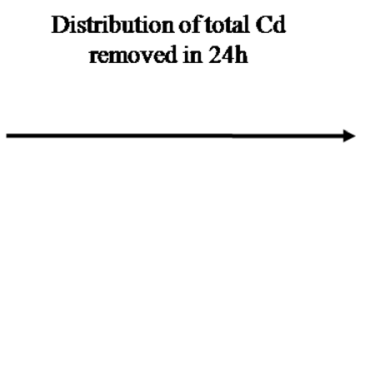

Distribution of total Cd

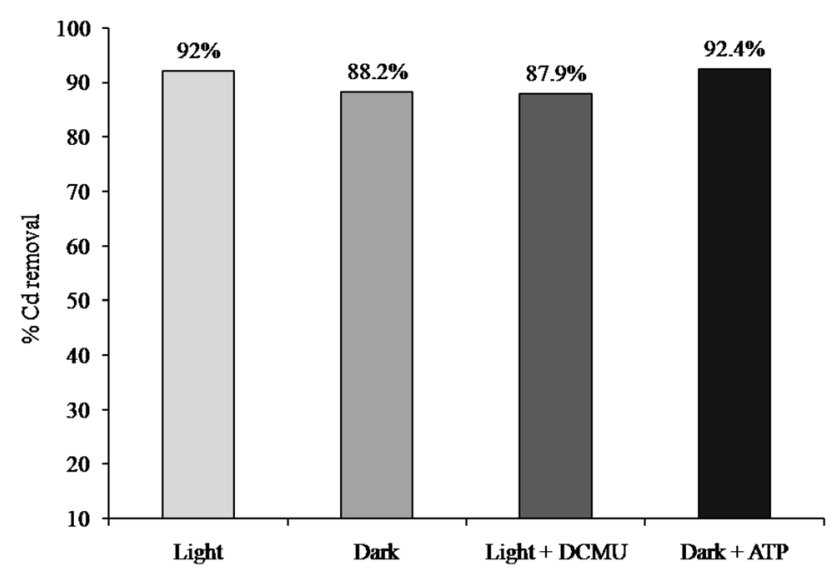

Fig. 5 Percent $\mathrm{Cd}$ removal under four different conditions: a light; b dark; c light + DCMU; and d dark + ATP. Cd concentration in the medium was $0.5 \mathrm{ppm}$ and the duration of the treatment was $24 \mathrm{~h}$

cases, availability of ATP during the experiment carried out in light or ATP externally supplied during the experiment carried out in dark resulted in an increase of $\sim 4 \%$ $\mathrm{Cd}$ removal from the $\mathrm{Cd}$ supplemented medium. This must be the $4 \%$ internally accumulated $\mathrm{Cd}$ that was recorded in cellular distribution study (Fig. 4b). This experiment provided evidence that although $\mathrm{Cd}$ removal was primarily sorption to the cell surfaces, the presence of high amount of $\mathrm{Cd}$ in the surrounding medium led to internal accumulation that required energy for transmembrane transport.

\section{Biosorption isotherm studies}

Biosorption of $\mathrm{Cd}$ was studied by fitting the data in the Langmuir, Freundlich and Temkin biosorption isotherm models (Fig. 6). The various isotherm parameters of Langmuir, Freundlich and Temkin are enlisted in Table 1. Among the isotherms, Langmuir was best fitted with an $R^{2}$ value of 0.98 as against that of Freundlich $R^{2}$ value of 0.94 and Temkin $R^{2}$ value of 0.86 . The maximum adsorption capability $Q_{\max }$ of the cyanobacterium for Cd was found to be $71.4 \mathrm{mg}$ of $\mathrm{Cd}$ taken up per $\mathrm{g}$ of biomass. The value of $n(7.69 \mathrm{~g} / \mathrm{L})$ showed the favorable $\mathrm{Cd}$ sorption by the cyanobacterium. Temkin isotherm constant, $B$ and $A_{\mathrm{T}}$ found to be $0.92 \mathrm{~L} / \mathrm{mg}$ and 55.07 , respectively, indicated the interaction between adsorbent and adsorbate was a favorable physical adsorption process. $R_{\mathrm{L}}$ value (separation factor) of 0.29 signified favorable interaction between the cyanobacterial cells and the $\mathrm{Cd}$ ions.

\section{Morphological, physiological and biochemical analysis}

\section{Scanning electron microscopic studies}

Control and Cd-treated Nostoc muscorum Meg 1 cells were viewed under SEM (Fig. 7). Extensive deformations with definite breaks in the filaments at several places were noticeable in the filaments. $\mathrm{Cd}$ at $0.5 \mathrm{ppm}$ concentration caused cell enlargement, elongation and shriveling in the cells within 3 days of exposure (Fig. 7b-d).

\section{Chlorophyll a: a measure of growth}

Growth in terms of chlorophyll $a$ showed a decreasing trend with increase in $\mathrm{Cd}$ concentration ranging from 0.1 to $1 \mathrm{ppm}$ from day 1 to day 3 (Fig. 8). The growth of control cultures increased by $14.5 \%$ on first day and $44.1 \%$ on third day. However, there was noticeable decline in chlorophyll $a$ concentration in all Cd-treated cultures. The percent reduction of chlorophyll $a$ content on very first day upon 0.1 , 0.2, 0.3, 0.5 and $1 \mathrm{ppm} \mathrm{Cd}$ exposure was found to be 1.2, 9.3, $13.1,20.3$ and $30.1 \%$, respectively, in comparison to control cultures. $\mathrm{Cd}$ at $0.5 \mathrm{ppm}$ concentration showed $\sim 51 \%$ reduction in chlorophyll $a$ within 3 days of Cd exposure. 

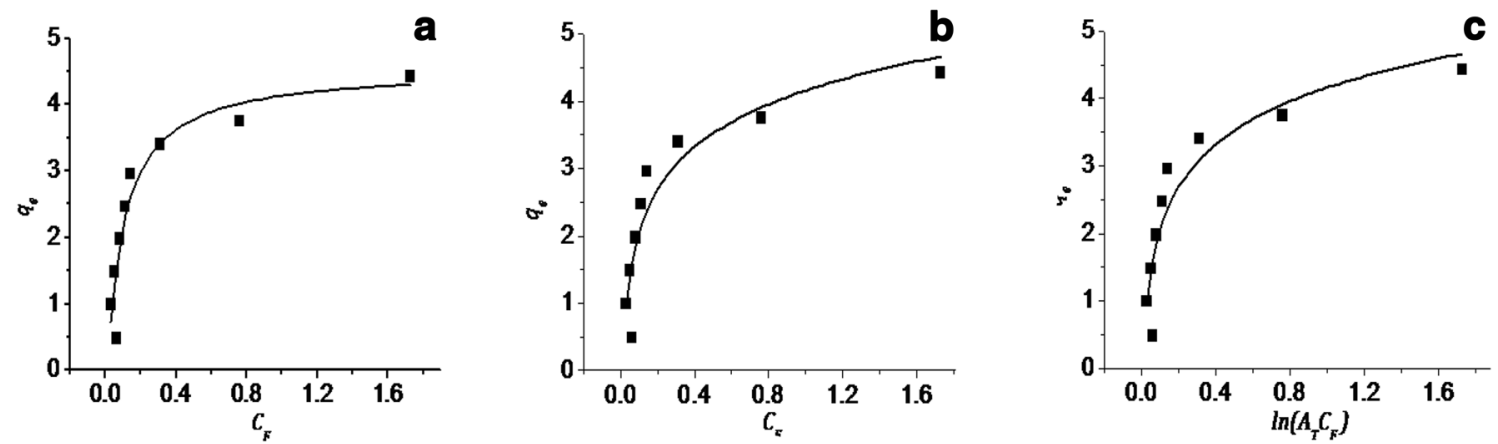

Fig. 6 Isotherm models; a Langmuir; b Freundlich; and c Temkin for Cd biosorption onto the cell surface of the cyanobacterium Nostoc muscorum Meg 1 at $25 \pm 2{ }^{\circ} \mathrm{C}$

Table 1 Langmuir, Freundlich and Temkin adsorption isotherm parameters of Cd-treated Nostoc muscorum Meg 1

\begin{tabular}{|c|c|c|c|c|c|c|c|c|c|c|}
\hline \multirow[t]{2}{*}{ Metal } & \multicolumn{4}{|l|}{ Langmuir } & \multicolumn{3}{|c|}{ Freundlich } & \multicolumn{3}{|c|}{ Temkin } \\
\hline & $Q_{\max }(\mathrm{mg} / \mathrm{g})$ & $K_{\mathrm{L}}$ & $R^{2}$ & $R_{\mathrm{L}}$ & $K_{\mathrm{F}}$ & $n$ & $R^{2}$ & $K_{\mathrm{T}}$ & $R_{T} / b_{\mathrm{T}}$ & $R^{2}$ \\
\hline Cd-treated cultures & 71.4 & 4.94 & 0.98 & 0.29 & 0.39 & 7.69 & 0.94 & 55.07 & 0.92 & 0.86 \\
\hline
\end{tabular}
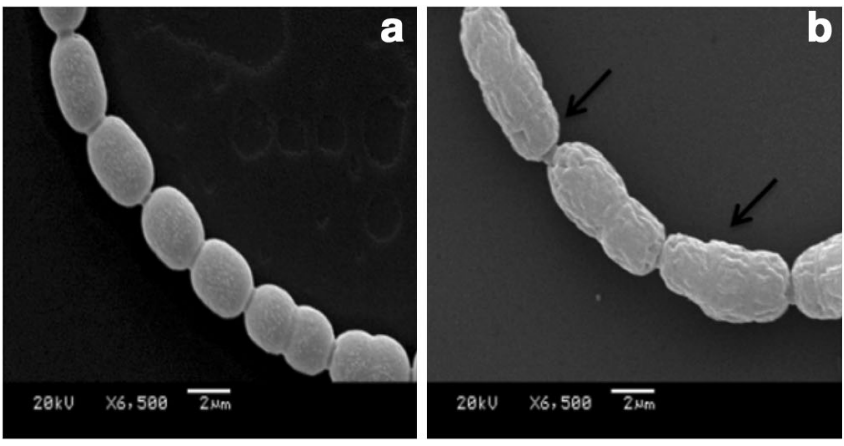

Fig. 7 Scanning electron micrographs of control and $0.5 \mathrm{ppm} \mathrm{Cd-}$ treated Nostoc muscorum Meg 1 cells. Duration of treatment: three days. a control; b-d Cd-treated cells (arrows in b indicate cell
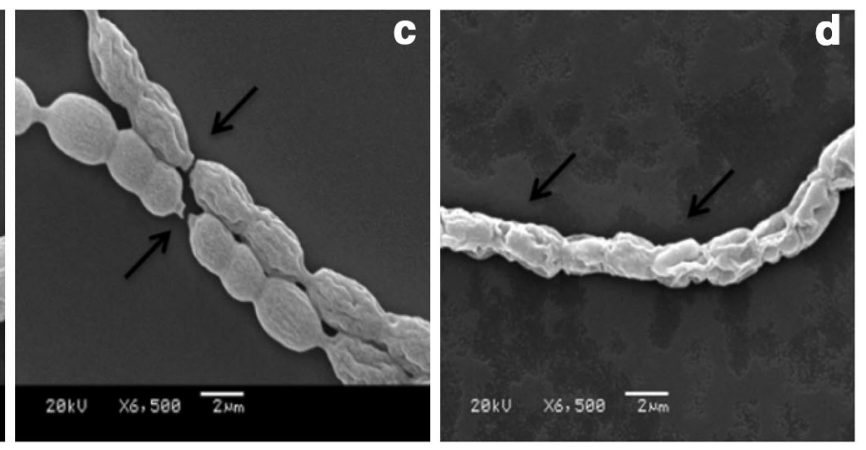

elongation and enlargement; arrows in c indicate broken filaments; arrows in $\mathbf{d}$ indicate cell deformation and shriveling)
Fig. 8 Chlorophyll

$a$ concentrations of control and

Cd-treated Nostoc muscorum

Meg 1 cells. Duration: 3 days.

Cd concentration: $(0.1-1 \mathrm{ppm})$.

All the values are mean \pm SD

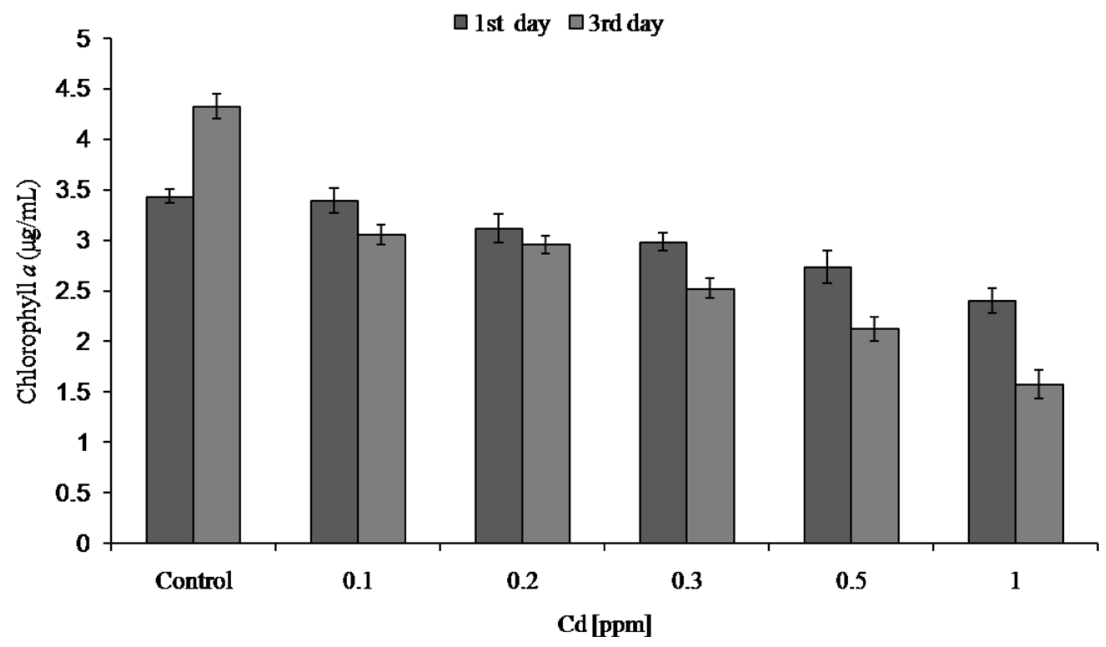




\section{Protein content}

Protein content of the cyanobacterium under $\mathrm{Cd}$ treatment displayed similar trend seen for chlorophyll $a$ study (Fig. 9). Untreated cells showed an increase of $\sim 16$ and $49 \%$ in protein concentration on day 1 and day 3 , respectively. However, adverse effect of Cd exposure was visible from day 1 itself on the organism. There was decrease in protein content by $9.7,17,30,36$ and $48.7 \%$ in the cultures treated with $0.1,0.2,0.3,0.5$ and $1.0 \mathrm{ppm} \mathrm{Cd}$, respectively, when protein content was measured after completion of one day treatment. A reduction of $\sim 53 \%$ in protein content was seen after day three on exposure to $0.5 \mathrm{ppm} \mathrm{Cd}$ emphasizing the toxic nature of $\mathrm{Cd}$ exposure.

\section{Nitrogen metabolizing machinery}

\section{Heterocysts frequency, nitrogenase and glutamine synthetase activities}

Exposure to $0.5 \mathrm{ppm} \mathrm{Cd}$ inhibited heterocyst frequency by $44 \%$ at the end of third day indicating that $\mathrm{Cd}$ could break down existing heterocysts in the filaments (Fig. 10a).

The activity of the $\mathrm{N}_{2}$-fixing enzyme nitrogenase was reduced by $\sim 40 \%$ and the glutamine synthetase (transferase) activity of the enzyme which assimilates fixed $\mathrm{NH}_{4}{ }^{+}$into amino acids was reduced by $38 \%$, within the same period of time (Fig. 10b).

\section{Discussion}

Many microbes including cyanobacteria have been shown to be present in polluted environments where there is predominance of various pollutants including heavy metals (Ozturk et al. 2014; Hazarika et al. 2015). Occurrence of

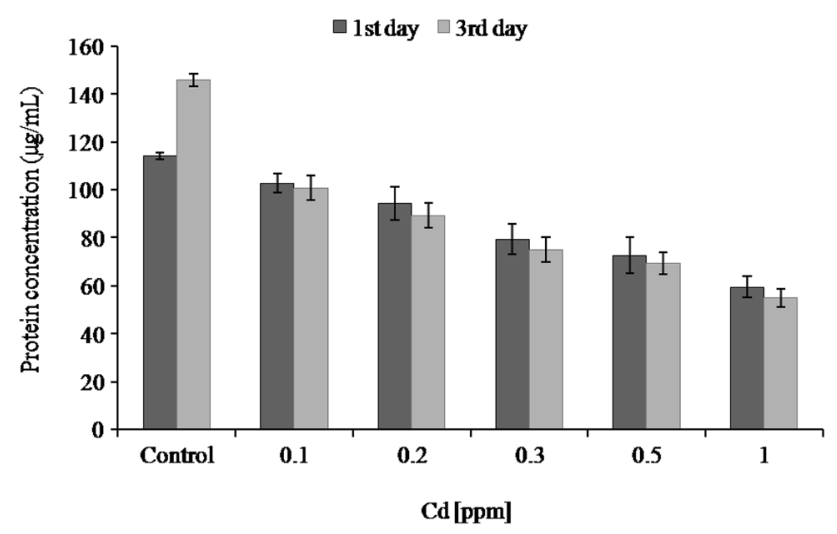

Fig. 9 Protein content of control and Cd-treated Nostoc muscorum Meg 1 cells. Duration: 3 days. Cd concentration: (0.1-1 ppm). All the values are mean $\pm \mathrm{SD}$ microbes in contaminated areas indicates their ability to acclimatize to such adverse conditions (Gadd 2010). One of the common heavy metal contaminants is $\mathrm{Cd}$ which is of growing concern due to its many known adverse effects on all living organisms. Jung (2001) and Goswami et al. (2015b) have reported the presence of $\mathrm{Cd}$ up to the level of $\sim 0.3 \mathrm{ppm}$ in coal mine-contaminated waters which is higher than the normal (0.1-0.2 ppm) occurrence of $\mathrm{Cd}$ in uncontaminated environment. A water analysis of the rice field from which the organism was purified recorded the presence of $\sim 0.22 \mathrm{ppm} \mathrm{Cd}$. The justification for exposing the organism to higher $\mathrm{Cd}$ concentration $(0.5 \mathrm{ppm})$ is that we wanted to see its tolerance to $\mathrm{Cd}$, its $\mathrm{Cd}$ removal ability and various morphological and physiological changes that have been brought about from its continuous exposure to high levels of $\mathrm{Cd}$ in its surrounding.

Our study during optimization of growth parameters established that best growth of Nostoc muscorum Meg 1 was at $\mathrm{pH} 8$ and temperature $25 \pm 2{ }^{\circ} \mathrm{C}$. $3 \mathrm{CdSO}_{4} \cdot 8 \mathrm{H}_{2} \mathrm{O}$ supplemented at this $\mathrm{pH}$ did not result in any metal precipitation in the medium. Since biomass is an important factor for metal removal and there was no metal hydroxylation at this $\mathrm{pH}, \mathrm{pH} 8$ was chosen for the study. The state of Meghalaya is a hilly area and temperature generally remains below $25{ }^{\circ} \mathrm{C}$ throughout the year except during summer season where temperature sometimes goes up to $27-28{ }^{\circ} \mathrm{C}$. Combined with the fact that this temperature $\left(25 \pm 2{ }^{\circ} \mathrm{C}\right.$ ) was found to be ideal for maximum biomass production and the organism was isolated from an environment where daily temperature remains in the range of 20-28 ${ }^{\circ} \mathrm{C}$ during rice growing season, $25 \pm 2{ }^{\circ} \mathrm{C}$ was chosen for the study. The initial metal removal study also provided evidence that at this temperature and $\mathrm{pH}$, very high percentage (92\%) of $\mathrm{Cd}$ was removed by the organism within $24 \mathrm{~h}$ of $0.5 \mathrm{ppm} \mathrm{Cd}$ exposure. FTIR and EDX studies confirmed $\mathrm{Cd}$ binding on to various cell surface groups. Carboxylic, carbonyl, hydroxyl, phenolic and phosphate moieties present in the cell surface of the cyanobacterium were found to participate in the $\mathrm{Cd}$ binding. In our study, we used three different isotherm models: Langmuir, Freundlich and Temkin to study biosorption of $\mathrm{Cd}$ on the cyanobacterium. Among these, Langmuir isotherm model is based on monolayer adsorption while Freundlich isotherm model is based on multi-layer adsorption. We also have included Temkin isotherm model which contains a factor that explicitly takes into account the adsorbent adsorbate interaction. These isotherms studies showed that the biosorption process fitted best in the Langmuir isotherm with $R^{2}$ value 0.98. The maximum $\mathrm{Cd}$ adsorption capacity, $Q_{\max }$, of the organism was $71.4 \mathrm{mg} / \mathrm{g}$. A comparative study showed that the Nostoc muscorum Meg 1 reported in this study had higher $Q_{\max }$ for $\mathrm{Cd}$ than Pseudomonas veronii 2E., Spirogyra insignis, Oscillatoria 
Fig. 10 a Heterocysts frequency (\%), b nitrogenase and glutamine synthetase activities in control and $\mathrm{Cd}$ treated Nostoc muscorum Meg 1 cells. Duration: 3 days. All the values are mean $\pm \mathrm{SD}$. Nitrogenase activity (nmol of $\mathrm{C}_{2} \mathrm{H}_{2}$ reduced/ $\mu \mathrm{g}$ of chl $\left.a / \mathrm{h}\right)$, GS activity (nmol of $\gamma$-glutamyl hydroxamate produced $/ \mu \mathrm{g}$ of protein/min)
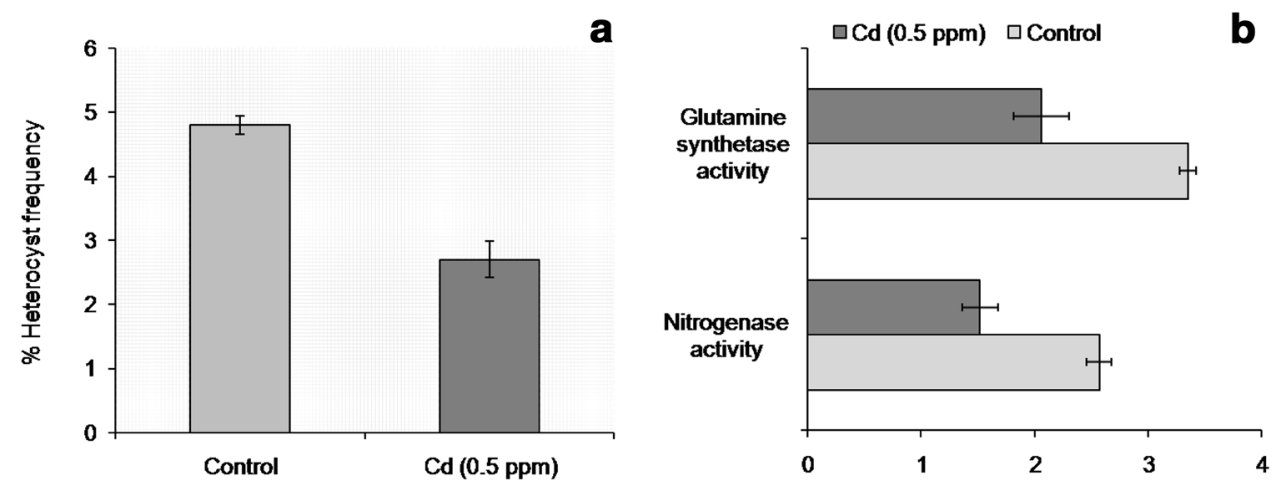

limosa and Gloeothece magna indicating its potential towards bioremediation of $\mathrm{Cd}$ from contaminated waters (Table 2). That this organism could play a significant role in Cd removal was also seen from the $R_{\mathrm{L}}$ value obtained from Langmuir isotherm discussed in the result. An $R_{\mathrm{L}}$ value between 0 and 1 (in this case 0.29 ) signified favorable interaction between the organism and $\mathrm{Cd}$. The $n$ value, $7.69 \mathrm{~g} / \mathrm{L}$ obtained from Freundlich isotherm again pointed towards the favorability of $\mathrm{Cd}$ sorption by the organism. The high percentage of Cd removal (92\% within $24 \mathrm{~h}$ ) corroborated the finding of Langmuir and Freundlich isotherms, i.e., favorable binding leading to high $\mathrm{Cd}$ removal. Toxicity of $\mathrm{Cd}$ on the organism was evident as within 3 days of exposure; the adverse effects of $\mathrm{Cd}$ were visible on its morphology. SEM pictures established the fact that on continuous exposure, $\mathrm{Cd}$ could induce cell elongation and enlargement, filament breakage as well as cell deformation. Cell enlargement was also reported by Khan et al. (2016) where they have attributed this phenomenon to biosorption of $\mathrm{Cd}$ in the bacterium Salmonella enteric $43 \mathrm{C}$.

That the organism was able to grow in the contaminated rice fields established its ability to tolerate presence of $\mathrm{Cd}$ in its vicinity. The high percent removal (92\%) achieved by the organism from the medium supplied with $0.5 \mathrm{ppm} \mathrm{Cd}$ further established its high $\mathrm{Cd}$ sorption ability. Our study further established that the maximum amount of $\mathrm{Cd}$ removal was a surface phenomenon in this cyanobacterium and did not require involvement of energy. The $4 \%$ of total removed $\mathrm{Cd}$ that has internally accumulated using energy may have compromised various enzymatic activities by virtue of being cationic in nature and producing oxidative stress. These adverse changes reflected in various physiological parameters such as growth measured by the content of chlorophyll $a$ and proteins; heterocysts frequency, nitrogenase and glutamine synthetase activities that were partially inhibited between 40 and $50 \%$ when exposed to $0.5 \mathrm{ppm} \mathrm{Cd}$, a value higher than that was found $(0.22 \mathrm{ppm})$ in Cd-contaminated rice fields in coal mining areas. $\mathrm{Cd}$ initiated break down of existing heterocysts as well as production of new ones. This in turn led to decline in $\mathrm{N}_{2}$ fixation and subsequent $\mathrm{NH}_{4}{ }^{+}$assimilation by glutamine synthetase. Whether the inhibition of nitrogenase and glutamine synthetase activities was a more direct affect of $\mathrm{Cd}$ could only be assessed with antibodies and immunoelectron microscopic studies that we plan to do in near future.

All these above findings established the fact that the presence of this cyanobacterium in the contaminated rice fields where $0.22 \mathrm{ppm} \mathrm{Cd}$ concentration was recorded is beneficial to the rice crop as the organism could remove a large percentage of $\mathrm{Cd}$, effectively reducing the toxic load of $\mathrm{Cd}$ in the water. All in all, although, $\mathrm{Cd}$ exposure adversely affected the well-being of the organism, $0.5 \mathrm{ppm}$ $\mathrm{Cd}$ concentration was not lethal. Thus in future, Nostoc muscorum Meg 1 could prove to be an attractive organism for biotechnological application performing dual function of bioremediation and biofertilizer in contaminated crop fields aiding to green chemistry.
Table 2 Cd biosorption of Nostoc muscorum Meg 1 and various other microbes reported in the recent past: a comparative analysis

\begin{tabular}{lcl}
\hline Name & Cd biosorption capacity (mg/g) & References \\
\hline Nostoc commune & 126.3 & Morsy et al. (2011) \\
Anabaena sphaerica & 111.1 & Abdel-Aty et al. (2013) \\
Nostoc muscorum Meg 1 & 71.4 & Present study \\
Pseudomonas veronii 2E & 54 & Vullo et al. (2008) \\
Spirogyra insignis & 22.9 & Romera et al. (2007) \\
Oscillatoria limosa & 10.8 & Mahalakshmi and Premkishore (2015) \\
Gloeothece magna & 4 & Mohamed (2001) \\
\hline
\end{tabular}




\section{Conclusion}

The Cd removal by Nostoc muscorum Meg 1 was a concentration-dependent process and was primarily by cell surface binding. The organism registered high $\mathrm{Cd}$ removal potential $(92 \%)$ and the ability to tolerate $\mathrm{Cd}$ in its surrounding. The maximum $\mathrm{Cd}$ adsorption capacity, $Q_{\max }$ $(71.4 \mathrm{mg} / \mathrm{g})$ of the organism was higher than many other microbes including Pseudomonas veronii 2E., Spirogyra insignis, and Oscillatoria limosa. The ubiquitous presence of this cyanobacterium in the rice fields indicated that it plays a significant role not only as biofertilizer but also as a bioremediator of heavy metals particularly $\mathrm{Cd}$, thereby reducing toxic $\mathrm{Cd}$ accumulation in rice plants and further in the food web. Overall, this study proved the tremendous potential of Nostoc muscorum Meg 1 in $\mathrm{Cd}$ removal from contaminated water.

Acknowledgement The authors would like to acknowledge University Grants Commission, New Delhi, Government of India for providing financial assistance under DRS-III, vide No. F. 4-9/2015/DRSIII (SAP-II) dated 23/04/2015. The first author thanks the Department of Science and Technology, New Delhi for providing INSPIRE Fellowship. The authors would like to thank SAIF, North-Eastern Hill University, Shillong for proving SEM-EDX and AAS facilities and the Department of Chemistry, North-Eastern Hill University, Shillong for providing FTIR facility.

\section{Compliance with ethical standards}

Conflict of interest The authors declare that there is no conflict of interest.

\section{References}

Abdel-Aty AM, Ammar NS, Ghafar HHA, Ali RK (2013) Biosorption of cadmium and lead from aqueous solution by fresh water alga Anabaena sphaerica biomass. J Adv Res 4:367-374

Aharoni C, Ungarish M (1977) Kinetics of activated chemisorptions. Part 2. Theoretical models. J Chem Soc, Faraday Trans 3:456-464

Atri N, Rai LC (2003) Differential responses of three cyanobacteria to UV-B and Cd. J Microbiol Technol 13:544-551

Ausubel FM, Brent R, Kingston RE, Moore DD, Seidman JG, Smith JA, Struhl K (1999) Agarose gel electrophoresis. Short protocols in molecular biology, 2nd edn. Wiley, New York

Babu BV, Gupta S (2008) Adsorption of Cr(VI) using activated neem leaves as adsorbent: kinetic studies. Adsorption 14:85-92

Cobette CS (2000) Phytochelatin and their roles in heavy metal detoxification. Plant Physiol 123:825-832

Deniz F, Saygideger SD, Karaman S (2011) Response to copper and sodium chloride excess in Spirulina sp. (Cyanobacteria). Bull Environ Contam Toxicol 87:11-15

Desikachary TV (1959) Cyanophyta. Indian Council of Agricultural Research, New Delhi

Dietary Reference Intakes for Vitamin A, Vitamin K, Arsenic, Boron, Chromium, Copper, Iodine, Iron, Manganese, Molybdenum, Nickel, Silicon, Vanadium, and Zinc (2001) A Report of the Panel on Micronutrients, Subcommittees on Upper Reference
Levels of Nutrients and of Interpretation and Uses of Dietary Reference Intakes, and the Standing Committee on the Scientific Evaluation of Dietary Reference Intakes, Food and Nutrition Board, Institute of Medicine, National Academy Press, Washington, D.C.

Dietz R, Riget F, Cleemann M, Aarkrog A, Johansen P, Hansen JC (2000) Comparison of contaminants from different trophic levels and ecosystems. Sci Total Environ 245:221-231

Dixit S, Singh DP (2013) Phycoremediation of lead and cadmium by employing Nostoc muscorum as biosorbent and optimization of its biosorption potential. Int J Phytoremediat 15:801-813

Gaber E, Yahia A, Adbdulrahim A (2012) Cadmium and lead biosorption by Chlorella vulgaris. Sixteenth Int Water Tech Conference, IWTC 16:1-12

Gadd GM (2010) Metals, minerals and microbes: geo-microbiology and bioremediation microbiology. Microbiol 156:609-643. doi:10.1099/mic.0.037143-0 (PMID 20019082)

Gallego SM, Pena LB, Barcia RA, et al. (2012) Unravelling cadmium toxicity and tolerance in plants: insight into regulatory mechanisms. Environ Exp Bot 83:33-46

Gallego SM, Pena LB, Barcia RA, Azpilicueta CE, Iannone MF, Rosales EP, Zwoznik MS, Groppa MD, Goswami S, Diengdoh OL, Syiem MB, Pakshirajan K, Kiran MG (2015) Zn (II) and Cu (II) removal by Nostoc muscorum: a cyanobacterium isolated from a coal mining pit in Chiehruphi, Meghalaya, India. Can J Microbiol 61:209-215

Goswami S, Syiem MB, Pakshirajan K (2015) Cadmium removal by Anabaena doliolum Ind1 isolated from a coal mining area in Meghalaya, India: associated structural and physiological alterations. Environ Eng Res 20(1):041-050

Gupta VK, Rastogi A (2008) Biosorption of lead (II) from aqueous solutions by non-living algal biomass Oedogonium sp. and Nostoc sp.-a comparative study. Colloids Suf B Biointerfaces 64:170-178

Haritash AK, Kaushik CP (2009) Biodegradation aspects of polycyclic aromatic hydrocarbons (PAHs): a review. J Hazard Mater 169:1-15

Hazarika J, Pakshirajan K, Sinharoy A, Syiem MB (2015) Bioremoval of $\mathrm{Cu}$ (II), $\mathrm{Zn}$ (II), $\mathrm{Pb}$ (II) and Cd (II) by Nostoc muscorum isolated from a coal mining site. J Appl Phycol 27(4):1525-1534. doi:10.1007/s10811-014-0475-3

Jin YN, Clark AB, Slebos RJC, Al-Refai H, Taylor JA, Kunkel TA, Resnick MA, Gordenin DA (2003) Cadmium is a mutagen that acts by inhibiting mismatch repair. Nat Genet 34(3):326-329. doi:10.1038/ng1172

Jung MC (2001) Heavy metal contamination of soils and waters in and around the Imcheon $\mathrm{Au}-\mathrm{Ag}$ mine, Korea. Appl Geochem 16:1369-1375

Keasling JD, Hupf GA (1996) Genetic manipulation of polyphosphate metabolism affects cadmium tolerance in Escherichia coli. Appl Environ Microbiol 62:743-746

Khan Z, Rehman A, Hussain SZ, Nisar MA, Zulfiqar S, Shakoori A (2016) Cadmium resistance and uptake by bacterium, Salmonella enteric 43C, isolated from industrial effluent. AMB Expr 6:1-16

Latifi A, Ruiz M, Zhang CC (2009) Oxidative stress in cyanobacteria. FEMS Microbiol Rev 33:258-278

Lowry OH, Rosebrough NJ, Farr AL, Randall RJ (1951) Protein measurement with Folin-phenol reagent. J Biol Chem 193:265-275

MacKinney G (1941) Absorption of light by chlorophyll solution. J Biol Chem 140:315-322

Mahalakshmi RM, Premkishore G (2015) Removal of heavy metals by biosorption using cyanobacteria isolated from freshwater pond. Int J Curr Microbiol App Sci 4(12):655-660 
Mallick N, Rai LC (1994) Removal of inorganic ions from wastewaters by immobilized microalgae. World J Micro Biotech 10:439-443

Mohamed ZA (2001) Removal of cadmium and manganese by a nontoxic strain of freshwater cyanobacterium Gloeothece magna. Wat Res 35(18):4405-4409

Morsy MF, Hassan SHA, Koutb M (2011) Biosorption of Cd(II) and $\mathrm{Zn}$ (II) by Nostoc commune: isotherm and Kinetics studies. Clean: Soil, Air, Water 39(7):680-687

Murakami M, Ae N, Ishikawa S, Ibaraki T, Ito M (2008) Phytoextraction by a high-Cd-accumulating rice: reduction of $\mathrm{Cd}$ content of soybean seeds. Environ Sci Technol 42:6167-6172

Nongrum NA, Syiem MB (2012) Effects of copper ion $\left(\mathrm{Cu}^{2+}\right)$ on the physiological and biochemical activities of the cyanobacterium Nostoc ANTH. Environ Eng Res 17(S1):125-132

Nubel U, Garcia-Pichel F, Muyzer G (1997) PCR primers to amplify 16S rRNA genes from cyanobacteria. Appl Environ Microbiol 63:3327-3332

Oguz E (2005) Adsorption characteristics and kinetics of the $\mathrm{Cr}(\mathrm{VI})$ on the Thuja oriantalis. Colloids Surf A Physicochem Eng Aspects 252:121-128

Ozturk S, Aslim B, Suludere Z, Tan S (2014) Metal removal of cyanobacterial exopolysaccharides by uronic acid content and monosaccharide composition. Carbohydr Polym 101:265-271. doi:10.1016/j.carbpol.2013.09.040

Prasanna R, Sood A, Rath SK, Singh PK (2014) Cyanobacteria as a green option for sustainable agriculture. In: Sharma NK, Rai AK, Stal LJ (eds) Cyanobacteria: an economic perspective. Wiley, London, pp 145-166

Qaiser S, Saleemi AR, Ahmad MM (2007) Heavy metal uptake by agro based waste materials. J Biotechnol 10:09-416

Rippka R (1988) Isolation and purification of cyanobacteria. In: Colowick SP, Kaplan NO, Packer L, Glazer AN (eds) Methods in enzymology (cyanobacteria), Vol 167. Academic Press San Diego, California 92101, pp 3-27

Ripkka R, Dereulles J, Waterbury JB, Herdman M, Stanier RY (1979) Generic assignments, strain histories and properties of pure cultures of cyanobacteria. J Gen Microbiol 111:1-61
Romera E, Gonzalez F, Ballester A, Blazquez ML, Munoz JA (2007) Comparative study of biosorption of heavy metals using different types of algae. Bioresour Technol 98:3344-3353

Sampaio MJAM, Rowell P, Stewart WDP (1979) Purification and some properties of glutamine synthetase from the nitrogen fixing cyanobacterium Anabaena cylindrica and Nostoc sp. J Gen Microbiol 111:181-191. doi:10.1099/00221287-111-1-181

Stewart WDP, Fitzgerald GP, Burris RH (1967) In-situ studies on nitrogen fixation using acetylene reduction technique. Proc Natl Acad Sci USA 58:2071-2078

Tamura K, Peterson D, Peterson N, Stecher G, Nei M, Kumar S (2011) MEGA5: molecular evolutionary genetics analysis using maximum likelihood, evolutionary distance, and maximum parsimony methods. Mol Biol Evol 28:2731-2739

Umrania VV (2006) Bioremediation of toxic heavy metals using acido thermophilic autotrophies. Bioresour Technol 97:171-173

Volesky B, Holan ZR (1995) Biosorption of heavy metals. Biotechnol Prog 11:235-250

Vullo DL, Ceretti HM, Daniel MA, Ramirez SAM, Zalts A (2008) Cadmium, zinc and copper biosorption mediated by Pseudomonas veronii $2 \mathrm{E}$. Bioresour Technol 99:5574-5581

Waalkanes MP (2003) Cadmium carcinogenesis. Mutat Res 533:107-120

Wolk CP (1965) Control of sporulation in a blue green alga. Dev Biol $12: 15-35$

Xiao X, Luo S, Zeng G, Wei W, Wan Y, Chen L, Guo H, Cao Z, Yang L, Chen J, Xi Q (2010) Biosorption of cadmium by endophytic fungus (EF) Microsphaeropsis sp. LSE10 isolated from cadmium hyperaccumulator Solanum nigrum L. Bioresour Technol 101:1668-1674

Zhang C, Sale PW, Doronila AI, Clark GJ, Livesay C, Tang C (2014) Australian native plant species Carpobrotus rossii (Haw.) Schwantes shows the potential of cadmium phytoremediation. Environ Sci Pollut Res 21:9843-9851 